\title{
Stratigraphy and depositional environment of late Pleistocene Sunakothi Formation in Kathmandu Basin, central Nepal
}

\author{
Mukunda Raj Paudel ${ }^{1}$ and Harutaka Sakai ${ }^{2}$ \\ ${ }^{1}$ Department of Geology, Trichandra Campus, Tribhuvan University, Ghantaghar, Kathmandu, Nepal \\ ${ }^{2}$ Department of Geology and Mineralogy, Kyoto University, Kyoto 606-01, Japan \\ ("Email: mukunda10@hotmail.com)
}

\begin{abstract}
Thick sandy sequences were recognised between the central and southern part of the basin, it was named as the Sunakothi Formation. We designate the type locality of this formation at Sunakothi, a village lying $3.0 \mathrm{~km}$ south of Patan. This formation is extensively distributed in the Nakhu, Kodku, and Godavari Kholas ranging in altitude from ca $1420 \mathrm{~m}$ in the southern margin to $1300 \mathrm{~m}$ in the central part. The average thickness of this formation ranges from 34 to $60 \mathrm{~m}$. The sedimentary strata are gently inclined towards the north. On the basis of geological mapping this formation is located between the muddy part of the Kalimati Formation of the ancient lake and the terrace gravel deposits. It is further divided into the following four parts: (1) muddy rhythmic basal part, (2) sandy lower part, (3) muddy, sandy, and gravelly middle part, and (4) laminated silty upper part. The basal part shows a transition from the lacustrine to fluvial environment in the south and the prodeltaic environment towards the basin centre. Its lower part contains sandy fluvial to lacustrine delta front deposits whereas the middle part comprises sandy bar, muddy floodplain, and gravelly channel-fill deposits. The upper part of this formation is restricted only to the southern end of the basin and shows marginal shallow lacustrine environments. The sedimentological evidence indicates that the Palaeo-Kathmandu Lake was drained out from the south due to tectonic activities as well as late Pleistocene climatic changes.
\end{abstract}

Keywords: Central Nepal, Kathmandu Basin, stratigraphy, depositional environment, paleo-lake

Received: 26 August 2008

revision accepted: 10 January 2009

\section{INTRODUCTION}

The sediments deposited in the intermontane basins of the Himalaya are the indicators of uplift tectonics and Monsoonal climate changes. The Kathmandu Basin with its upper $200 \mathrm{~m}$ muddy lacustrine and overlying fluvio-deltaic sediments plays an important role in deciphering the late Pleistocene climate and its relation to the Himalayan uplift. Stratigraphic, palaeoclimatic, and palaeoenvironmental works in the basin-fill sediments have been carried out by many researchers (Yoshida and Igarashi 1984; Dongol 1985; Yoshida and Gautam 1988; Sakai et al. 2001; Fujii and Sakai 2002). Geological field investigations in the southern part of the Kathmandu Valley revealed that the Paleo-Kathmandu Lake came into existence after the damming of the Protobagmati River by the fanglomerates derived from the southern mountain chain. The drill core data from Dukuchhap, a village situated in the southern margin of the basin, indicated that the damming took place about $1 \mathrm{Ma}$ ago (Sakai et al. 2002). This fanglomerate directly overlies the gravelly and sandy beds of the Proto-Bagmati River flowing from north to south in the Kathmandu Valley (Paudel and Sakai 2004). On the other hand, there are many unsolved problems regarding the sedimentary processes and timing of draining of the lake water from the south. Previous authors pointed out to the upheavel of the southern Mahabharat range and consequent migration of the ancient lake towards the central portion of the Kathmandu Valley. As a result, three terrace levels were formed above the ancient lake (Yoshida and Igarashi 1984; Yoshida and Gautam 1988). According to a Newari legend, the Bodhisatva Manjushree from Tibet cleft the hill of Chobhar with one blow of his sword, and the lake water was drained out. Sakai (2001) reported an active fault, which intersects the Quatenary deposits in the southern part of the valley and discussed that it may have played a role of drainage way. In addition, he and his co-workers clarified that the muddy lacustrine deposits (the Kalimati Formation) are unconformably overlain by the fluvial sediments (the Patan Formation) and their boundary was assigned an age of about $10 \mathrm{ka}$ (Libby age) on the basis of AMS ${ }^{14} \mathrm{C}$ dating of drill cores at Rabibhawan and Tri-Chandra Campus (Sakai et al. 2001).

In previous studies, thick sandy and gravelly deposits were recognised between the central and southern parts of the Kathmandu Basin and they were named as the Sunakothi Formation (Sah et al. 1995; Sawamura 2001). Sah et al. (1995) showed that the Sunakothi Formation represented a lateral 

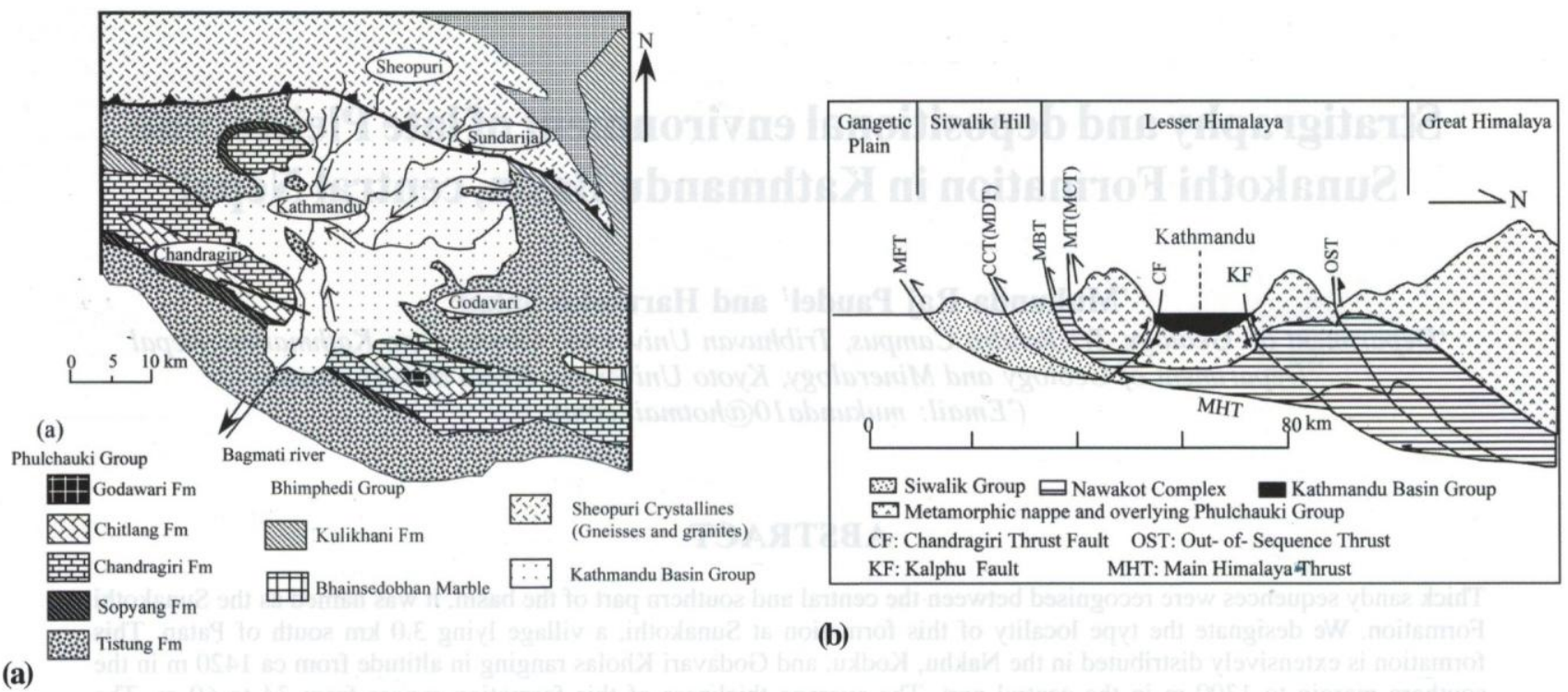

(b)

Fig. 1: (a) Geological map of central Nepal around Kathmandu Valley (Modified from Rai 2001, Stöcklin and Bhattarai 1977); (b) Simplified geological cross-section of central Nepal (Sakai 2001).

facies change of the Lukundol Formation and showed its distribution within a narrow zone in their geological map. On the other hand, this formation was regarded to be the southern continuation of the fluvio-deltaic formation, called the Gokarna-Thimi Formation (Yoshida and Igarashi 1984; Sakai 2001b). Since this formation plays a key role in deciphering the history of the ancient lake, we carried out geological mapping in the southern part of the Kathmandu Valley and examined the vertical and lateral sedimentary facies changes in the Sunakothi Formation.

\section{GEOLOGICAL SETTING}

The Kathmandu Basin measures approximately $30 \mathrm{~km}$ in $\mathrm{E}-\mathrm{W}$ and $25 \mathrm{~km}$ in $\mathrm{N}-\mathrm{S}$ directions with a nearly circular outline. This basin is situated (Figs.1a and 1b) on the Kathmandu Nappe (Stöcklin 1980; Stöcklin and Bhattarai 1977; Rai 2001; Sakai 2001). The rocks of this nappe constitute the Kathmandu Complex ranging in age from Precambrian to Palaeozoic. According to Stöcklin and Bhattarai (1977) the fossiliferous early Palaeozoic Tethyan rocks of the Phulchauki Group rest on the metamorphosed Bhimphedi Group. There are small ridges within the basin composed of quartzites, slates, and limestones. One of such prominent ridges runs NW-SE across the basin between Kirtipur and Chobhar. The northern slope of the Kathmandu Valley is composed of gneisses, granites, and schists (Fig.1b). These slopes are bounded by the Kalphu Fault in the north and Chandragiri Fault in the south (Sakai 2001). The remaining slopes and valley floor consist of metasediments (Fig.1b). Therefore, the sources of basin-fill sediments are either metasediments or granites, gneisses, and schists (Sakai 2001).
The basin-fill sediments are more than $500 \mathrm{~m}$ thick (Moribayashi and Mauro 1980, Katel et al. 1996). From the north came the fine sediments (mainly sand and silt) that filled up mostly the northern half. These sediments are of fluvio-deltaic origin (Sakai 2001; Dill et al. 2001). In the south pebbly clay, conglomerate, and diatomaceous earth are predominant. Though peat, clay, and diatomaceous earth occur in different parts, they are confined essentially to the central and southern portions of the valley.These sediments are broadly divided into the three sedimentary facies: fluviodeltaic in the north, fluvio-lacustrine in the south and central portion, and alluvial fan and fluvial deposits in the southern margin of the basin (Fig. 2).

\section{Sunakothi Formation}

The Sunakothi Formation is located above the muddy part of the Kalimati Formation and is covered by the terrace gravel deposits (Figs. 3 and 4). It is extensively distributed in the southern part of the Kathmandu Basin at altitude ranges from $\sim 1420 \mathrm{~m}$ in the southern margin to $1300 \mathrm{~m}$ in the central part. We have designated the type locality of this formation at Sunakothi, a village situated about $3 \mathrm{~km}$ south of Patan. Other well exposed sections of this formation are observed in the upper reaches of the Godavari Khola (at Damaitar), in the Nakhu Khola, at the confluence of the tributary from Dhapakhel and the Kodkhu Khola, and in the Khayakadol Khola between Jorkhu and Parigaon situated in the southernmost part of the Kathmandu Basin (Fig. 3). The thickness of this formation ranges from 34 to $60 \mathrm{~m}$ and it attains a maximum value between the central and southern portions of the basin where thick fluvial gravels are interbedded with sandy and muddy sequences. 


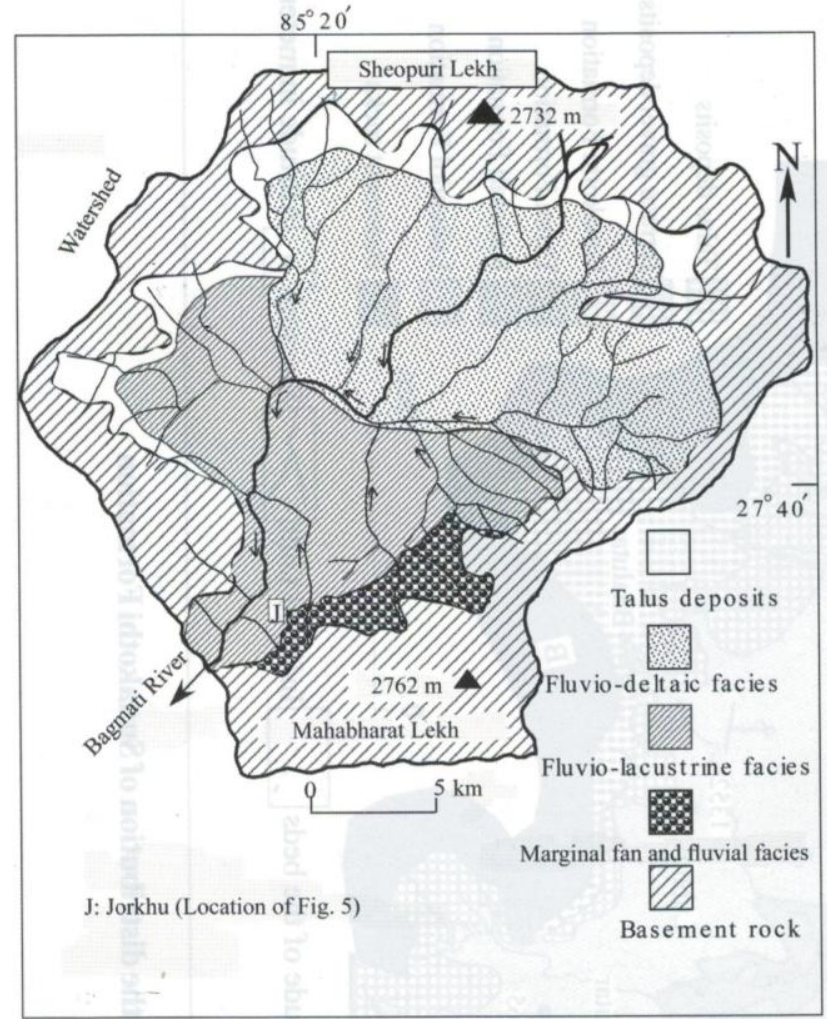

Fig. 2: Map of basin-fill sediments in Kathmandu Valley showing fluvio-deltaic, fluvio-lacustrine, and fan facies (modified from Sakai 2001)

The Sunakothi Formation consists of massive to laminated, thick- to thin-bedded, grey to dark grey clay, silty clay, coarse- to fine-grained sand with occasional white diatomaceous silt, carbonaceous black clay, and pebble- to large boulder-size gravels. The main sedimentary structures observed in this formation are large- to small-scale crossbeddings, parallel and climbing ripple laminations, sporadic wave ripples, and trough and flaser laminations. Fine-grained sand and silt beds contain climbing ripple laminae, while medium- and coarse-grained sand beds contain small- to large-scale cross-beddings. Synsedimentary deformation structures such as slump and distorted bedding, deformed sedimentary layers, and small-scale faults are present in this formation. Frequently the beds strike NW to SE and dip from $4^{\circ}$ to $8^{\circ}$ (up to $12^{\circ}$ at some places) due N. Their angle of dip systematically decreases towards the centre of the basin.

\section{Lithological description of Sunakothi Formation}

On the basis of dominant lithology, the Sunakothi Formation is divided into the following four parts (Fig. 5).

(1) The basal part is from 2.5 to $19 \mathrm{~m}$ thick and comprises two sequences. The first one contains mainly black to grey muddy rhythmites in the south (Figs. 6a and 6b). The rhythmites are 2.5 to $2 \mathrm{~m}$ thick and consist of 0.3 to $1 \mathrm{~cm}$ thick, light grey, very fine silty sand and silt transitionally passing into dark grey silty clay. The thickness of each couplet varies from $7 \mathrm{~mm}$ (at the base) to $4 \mathrm{~cm}$ (towards the top). These couplets are horizontal to gently inclined towards the north. Light and grey coloured laminae are thicker in the basal part. Carbonaceous fragments are present within the muddy rhythmites. The boundary between the light to dark coloured layers is gradational, whereas the base of light coloured layers is sharp.

The second sequence is composed of silt and very finely laminated silty sand with plant remains (leaves and fragments), gastropods, and trapa. This sequence is thicker than the first sequence of muddy rhythmites and is mainly distributed towards the basin centre. The boundary between the basal part of the Sunakothi Formation and underlying muddy part of the Kalimati Formation is slightly erosional to gradual (Fig. 6).

(2) The lower part is 2.5 to $22 \mathrm{~m}$ thick and consists mainly of thick sandy fluvial sequences characterised by crossstratification and ripple drift cross-lamination (Fig. 7). It is a sand-dominated sequence in the south whereas it contains an increasing proportion of mud towards the north where its thickness decreases significantly. Green coloured sand is the characteristic feature of this part. Carbonaceous wood fragments frequently occur in the sandy sequence. The sand beds are intercalated with very thin silt beds. In some localites the sand beds show wavy and distorated bedding and minor faults. The lenticular sand beds are intercalted with very thin silt and mud beds. The sand beds contain large- to small-scale cross-laminations whereas the silt beds contain climbing ripples and very small-scale cross-bedding. Some sand beds show crosscutting relation, very low angle crossbedding (Figs. 7c and 7d), well laminated coarse and fine sand intercalations are characteristics of the lower part.

(3) The middle part is 10 to $38 \mathrm{~m}$ thick and is made up of sand- and mud-dominated sequences with thick lenticular gravels (Fig. 8). This part is composed of three sequences: a) coarse fluvial sand and gravel, b) alternating fine and coarse sand, and c) highly bioturbated, carbonaceous, leafand trapa-containing, muddy or silty fine sand. This part is the thickest and widely distributed from the south to the centre of the basin (Fig. 10). Both fining- and coarseningupwards sequences are clearly seen within this part. Coarse and fine intervals are the distinguishing characteristics of this part. Various types of slump and convolute structures also frequently occur in it (Fig. 8).

(4) The upper part is 4 to $22 \mathrm{~m}$ thick and composed of laminated sand and silt. It is distributed only at the southern margin of the basin. Some silt beds of this part contain plant fragments and leaves (Fig. 9). Frequently the sand and silt are black colured and bioturbated. Sand beds containing climbing ripples are present within the silty rhythmites. This part is unconformably overlain by 2 to $25 \mathrm{~m}$ thick fluvial terrace gravel (Fig. 10). 
Mukunda Raj Paudel and Harutaka Sakai

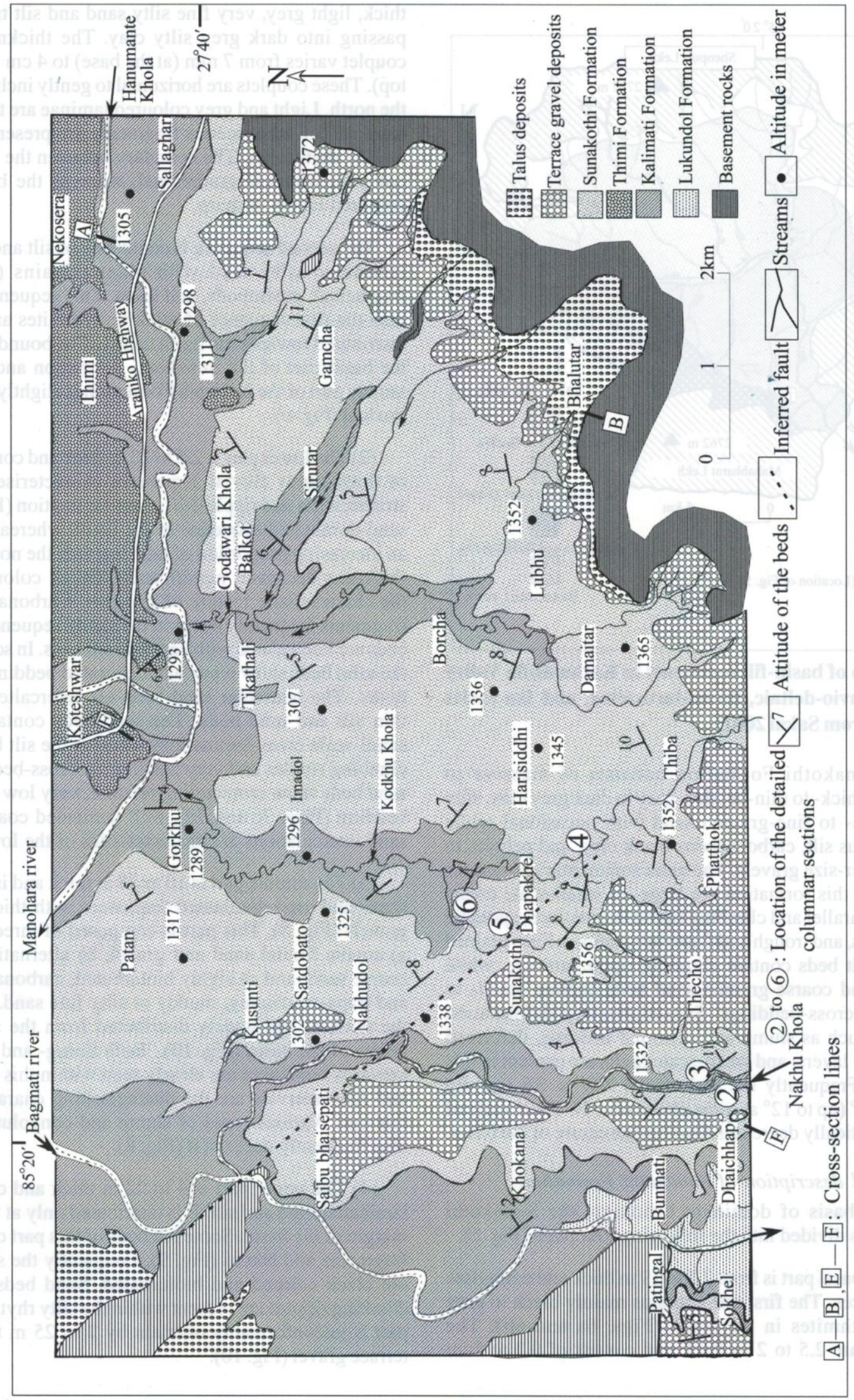

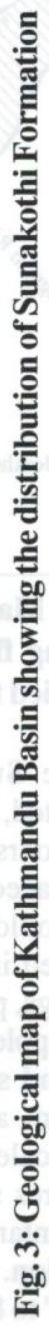


(a)
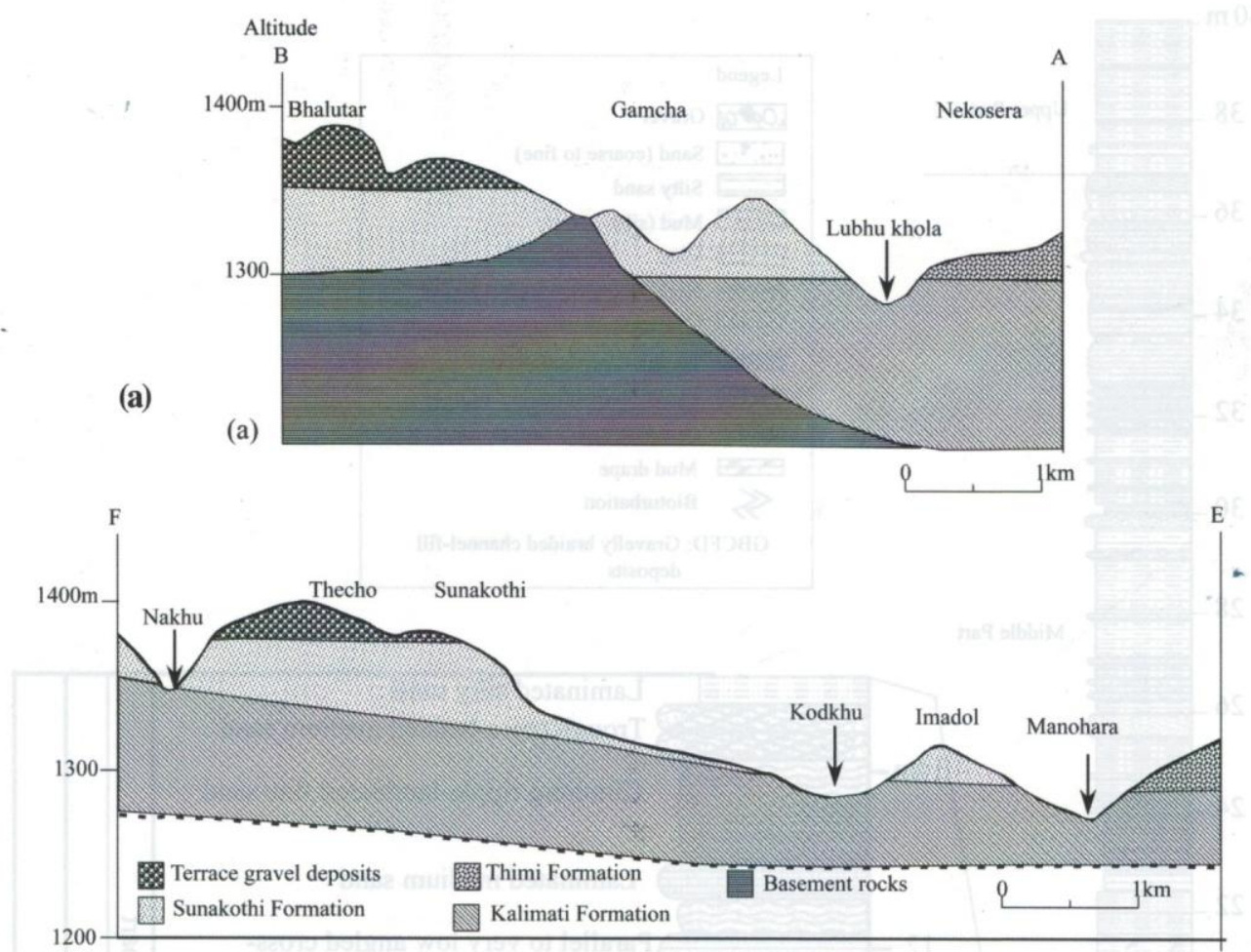

(b)

(b)

Fig. 4: Geological cross-sections ( $a$ and b) showing fluvio-lacustrine facies of the Sunakothi Formation overlying muddy lacustrine facies of the Kalimati Formation and underlying fluvial terrace deposits

\section{DISCUSSIONS}

The Sunakothi Formation displays some distinctive characteristics in terms of its lithology, palaeocurrent directions, depositional environment, and climatic and tectonic control on sedimentation.

\section{Lithology}

The detritus was derived mainly from metasandstones and the white sand was mainly of quartzite origin. Most of the sandy sequences are highly weathered and exhibit reddish brown and yellow coloration. The XRD analysis and thin section studies of these sediments revealed mica, quartz, feldspar (plagioclase and K-feldspar) and a minor amount of chlorite. Quartz and feldspar are the main constituent minerals and the amount of quartz ranges from 40 to 80 weight per cent in the bulk sediments.

\section{Palaeocurrent directions}

The dominant palaeocurrent direction depicted by largescale cross-stratifications is from south, whereas small-scale cross-laminae and climbing ripple laminae show fluctuating directions (e.g., from south, west, southeast, and north). Though the orientation of drainage and palaeoslopes differed from place to place, they were mainly directed towards the centre (Fig. 10). The palaeocurrent directions and clast compositions indicate that the sediments were derived from the south and southeast of the Kathmandu Valley.

\section{Depositional environments}

The detritus of the Sunakothi Formation and overlying gravel beds was derived mainly from the quartzites and sandstones of the Tistung Formation exposed in the Mahabharat range to the south. The sedimentological study in the southern part of the basin revealed that the Sunakothi Formation was deposited in fluvial and shallow lacustrine environments. Several beds of lacustrine and fluvial alternations show that the area experienced dry as well as humid climates during the sedimentation period. In the dry period, the fluvial deposits like sands, gravels, and pebbles were accumulated whereas in the humid period, laminated or massive clay and laminated silt beds were formed. Hence, the transition from ancient lacustrine to alluvio-fluvial system in the Palaeo-Kathmandu Lake is characterised by a sandy and gravelly braided river at its basal and proximal parts to a meandering river at its top and distal parts. The basal part of this formation is composed of muddy rhythmites showing a slightly erosional or transitional contact with the underlying muddy succession of the Kalimati Formation. The muddy succession contains opercula layers indicating sedimentation in calm water, probably in the offshore region. 


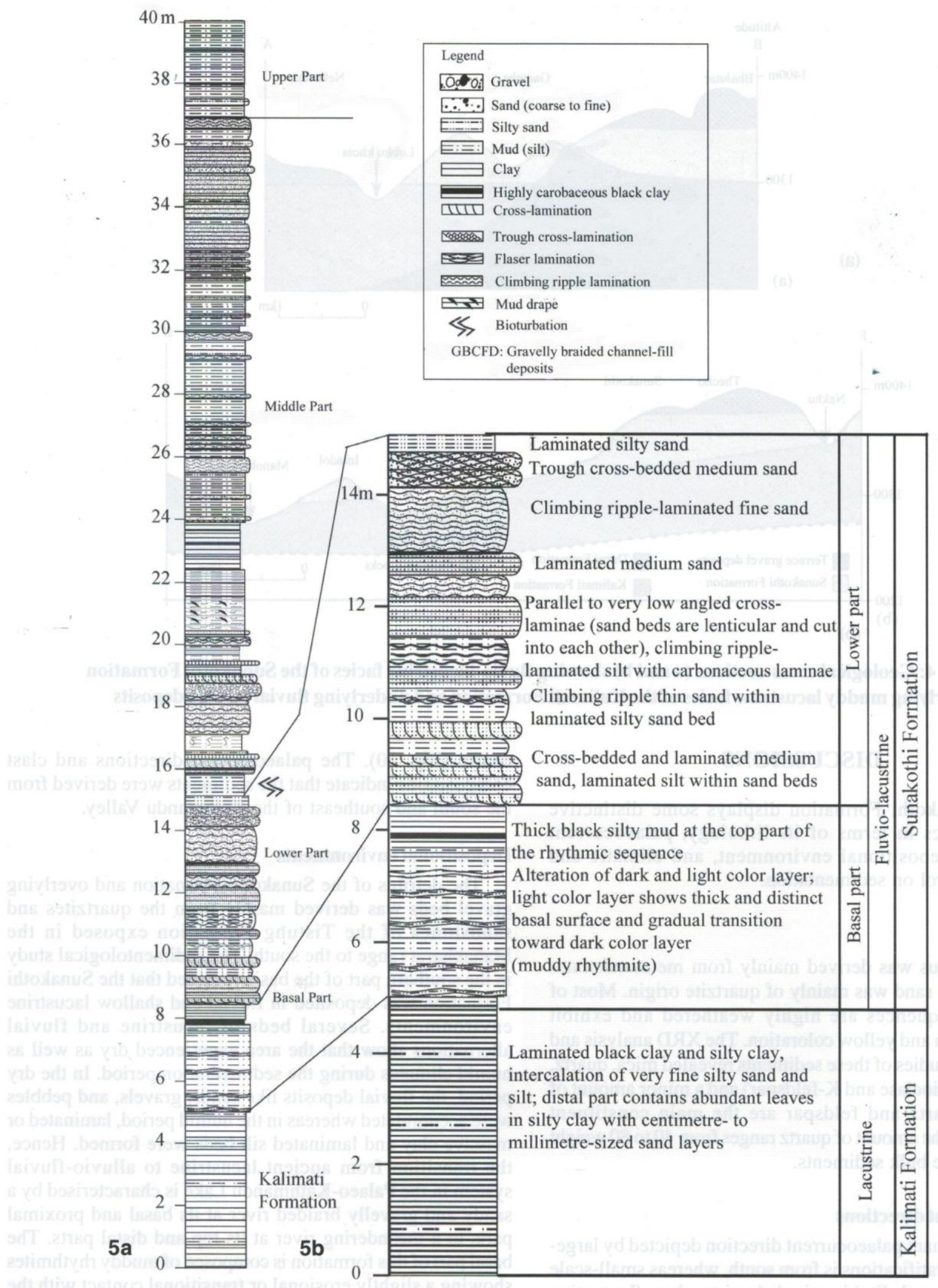

Fig. 5a: Detailed lithostratigraphic section of the Sunakothi Formation from Jorkhu (type locality) in the southern part of the Kathmandu (see Fig. 2 for location). Fig. $5 \mathrm{~b}$ depicts the Kalimati Formation as well as basal and lower parts of the Sunakothi Formation whereas Fig. $5 \mathrm{c}$ (see facing page) shows the middle and upper parts of the Sunakothi Formation. 
Continued...

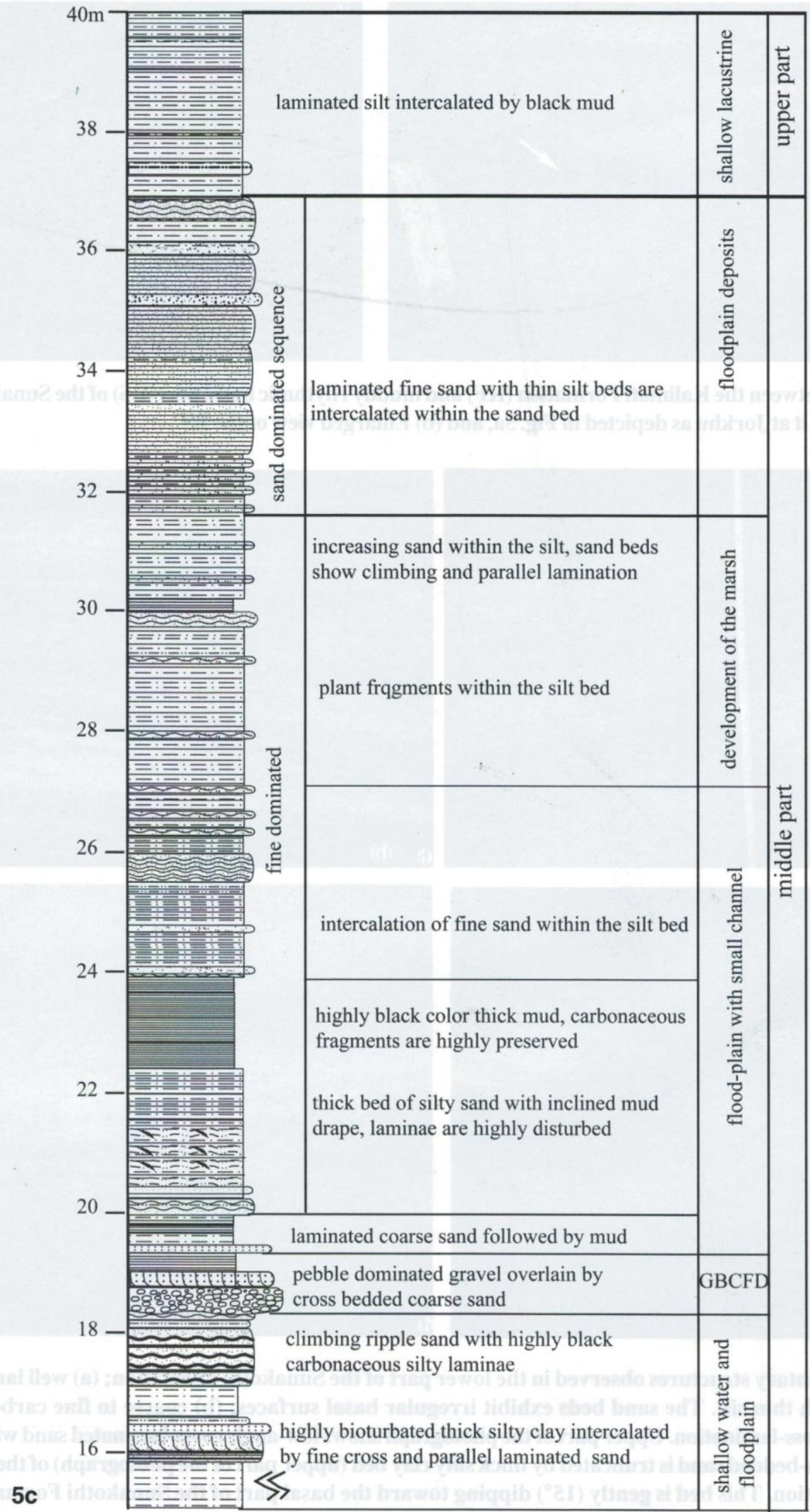



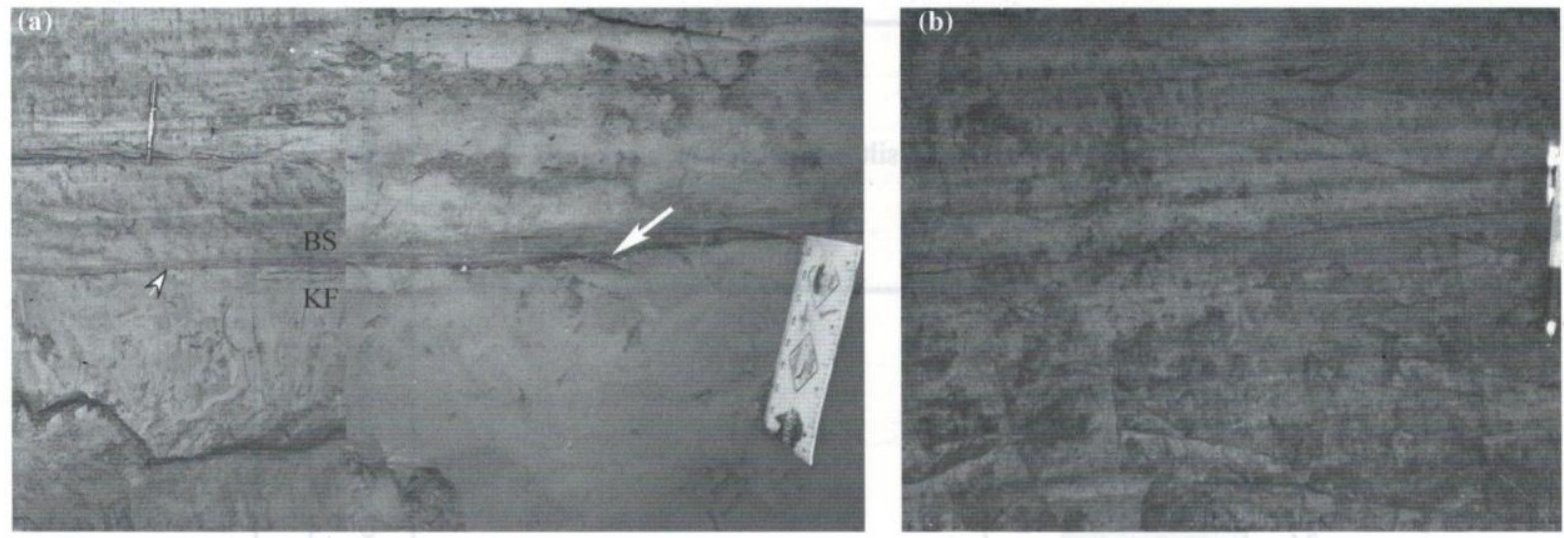

Fig. 6: (a) Boundary between the Kalimati Formation (KF) and muddy rhythmic basal part (BS) of the Sunakothi Formation (SF) above it at Jorkhu as depicted in Fig. 5a, and (b) Enlarged view of the BS
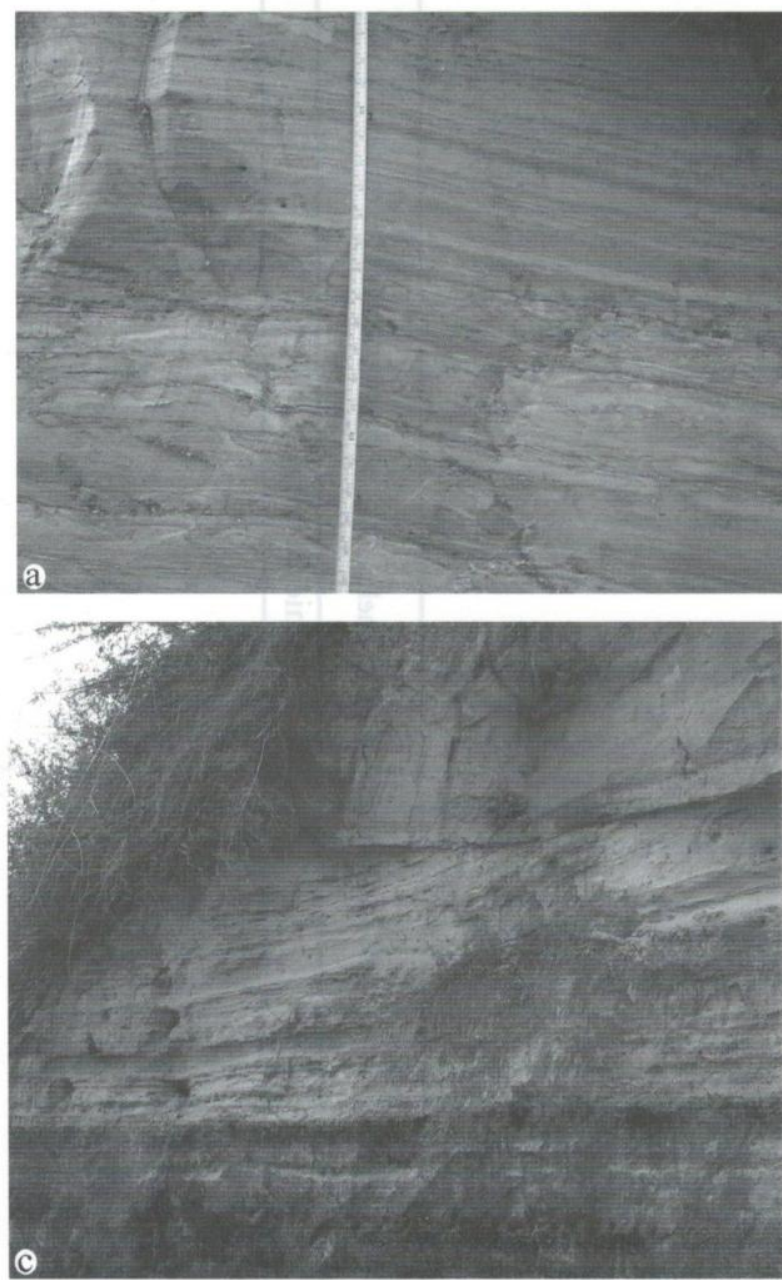
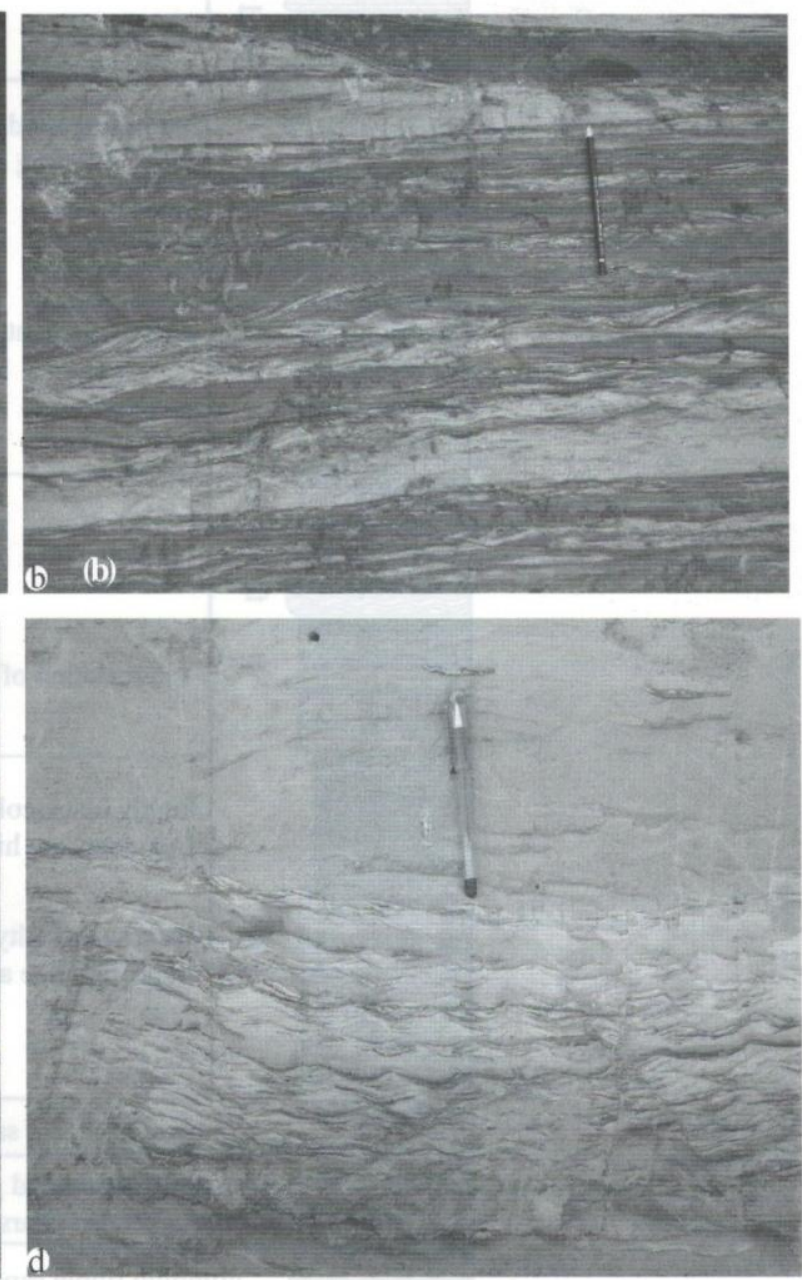

Fig. 7: Various sedimentary structures observed in the lower part of the Sunakothi Formation; (a) well laminated coarse sand intercalated with thin silt. The sand beds exhibit irregular basal surfaces; (b) coarse to fine carbonaceous sand showing ripple drift cross-lamination. Upper part of the photograph shows low-angle cross-laminated sand with crosscutting relation; (c) thick cross-bedded sand is truncated by thick silty clay bed (upper part of the photograph) of the middle part of the Sunakothi Formation. This bed is gently $\left(15^{\circ}\right)$ dipping toward the basal part of the Sunakothi Formation; (d) wavy climbing ripple laminated succession overlain and underlain by massive coarse sand 

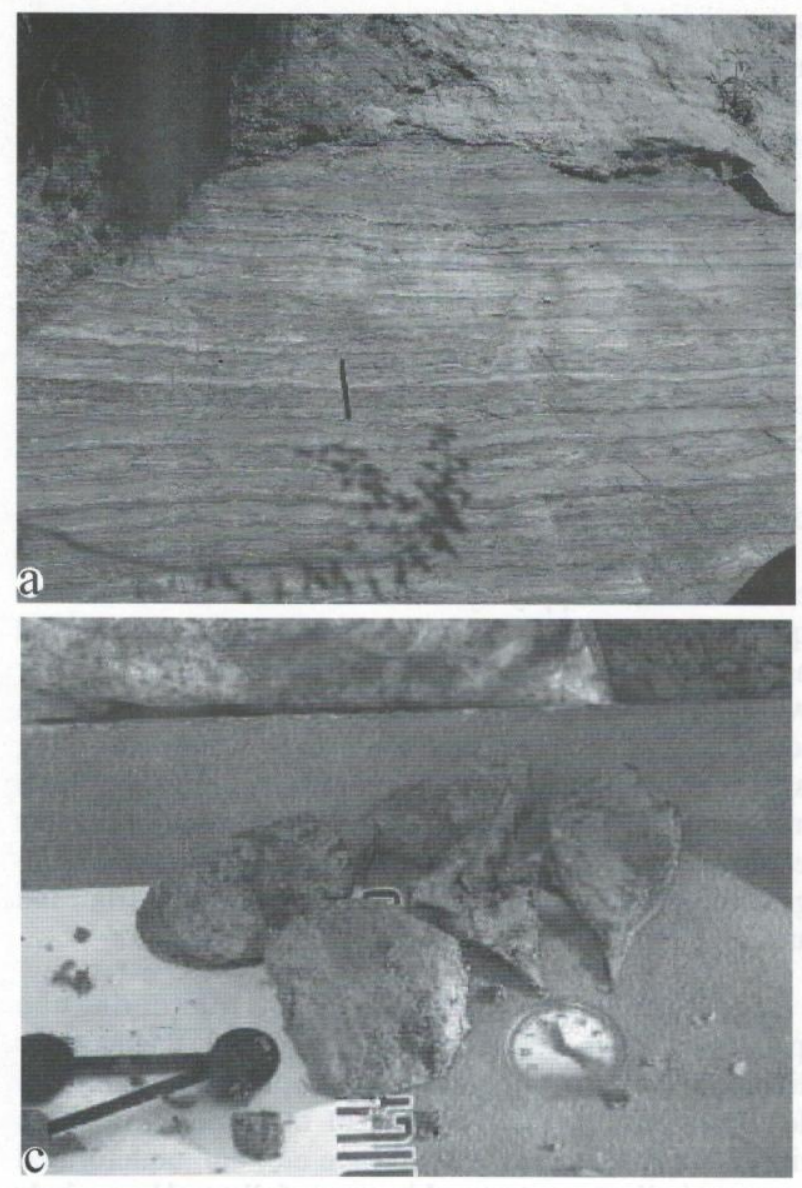
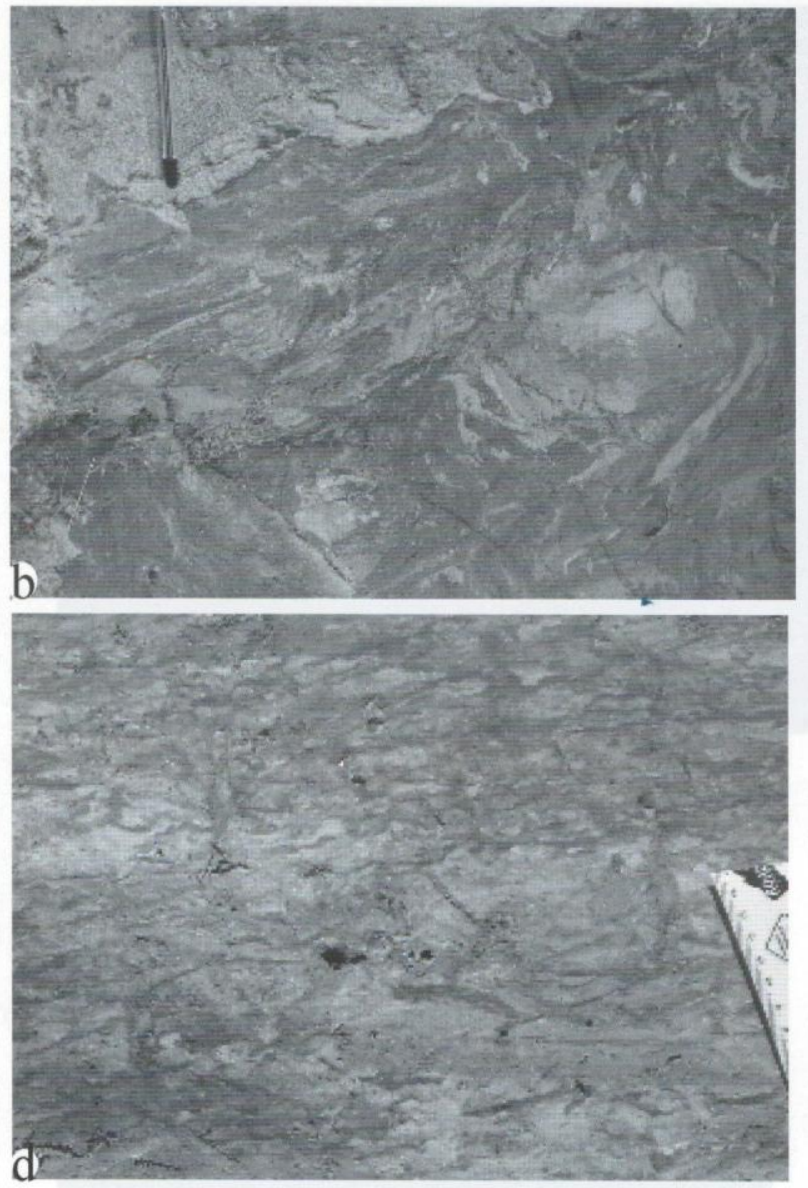

Fig. 8: Various facies comprising the middle part of the Sunakothi Formation; (a) alternating fine and coarse sediments. The fine interval is mainly grey silt whereas the coarse interval is fine red sand; (b) slump beds within black to dark grey silt beds; (c) trapa fossils within the silt beds of the middle part of the Sunakothi Formation; (d) highly bioturbated very fine silty sand and silt

The basal part at the southern margin (Fig. 5a) is composed of $\sim 2.5 \mathrm{~m}$ thick, white diatomaceous and nondiatomaceous black layers (Fig. 6). They indicate water level fluctuations due to the seasonal climatic changes before draining out of the lake water from the southern margin. The basal part of the Sunakothi Formation changes into prodeltaic and shallow lacustrine deposits towards the basin centre.

The Sunakothi Formation is represented by a succession of sand, silt, and mud with the intercalation of thick, lenticular gravel beds in the central part of the Kathmandu Basin. This sequence indicates that the flood-dominated fluvial system to the south changed into a small lacustrine deltaic system toward the centre of the basin. While moving from south to the lake centre, the lower parts of thick sand beds change their colour from grey to green and they are represented by medium to coarse sand with cross- and climbing ripple laminae. These sedimentary features indicate a fluvial environment of deposition (in the south) passing into a lacustrine delta front (at the centre). The middle part of the Sunakothi Formation was deposited in a sandy braided river passing into a very shallow lake or meandering river. Frequently, a higher-energy gravelly braided river interrupted the sandy and muddy environment. On the other hand, the thin clay beds of the middle part were continuously and slowly deposited while the silty and fine sandy layers settled down very quickly. Such conditions are generally observed in a lacustrine delta (Reineck and Singh 1980). The upper part of the Sunakothi Formation (which is distributed only in the south) was deposited in a marginal shallow lake (Fig. 10). The existance of this marginal lake can be attributed to the activity of the Chandragiri Fault, which could have temporarily dammed the Kathmandu basin's outlet.

\section{Climatic and tectonic controls on sedimentation}

Extensive distribution of thick clastic detrital sequence from the south to the central part of the Kathmandu Basin indicates that a wide space was available for the deposition of the Sunakothi Formation. This was probably due to a high uplift rate of the Mahabharata range to the south and Sheopuri range to the north. The thick muddy sequence of 

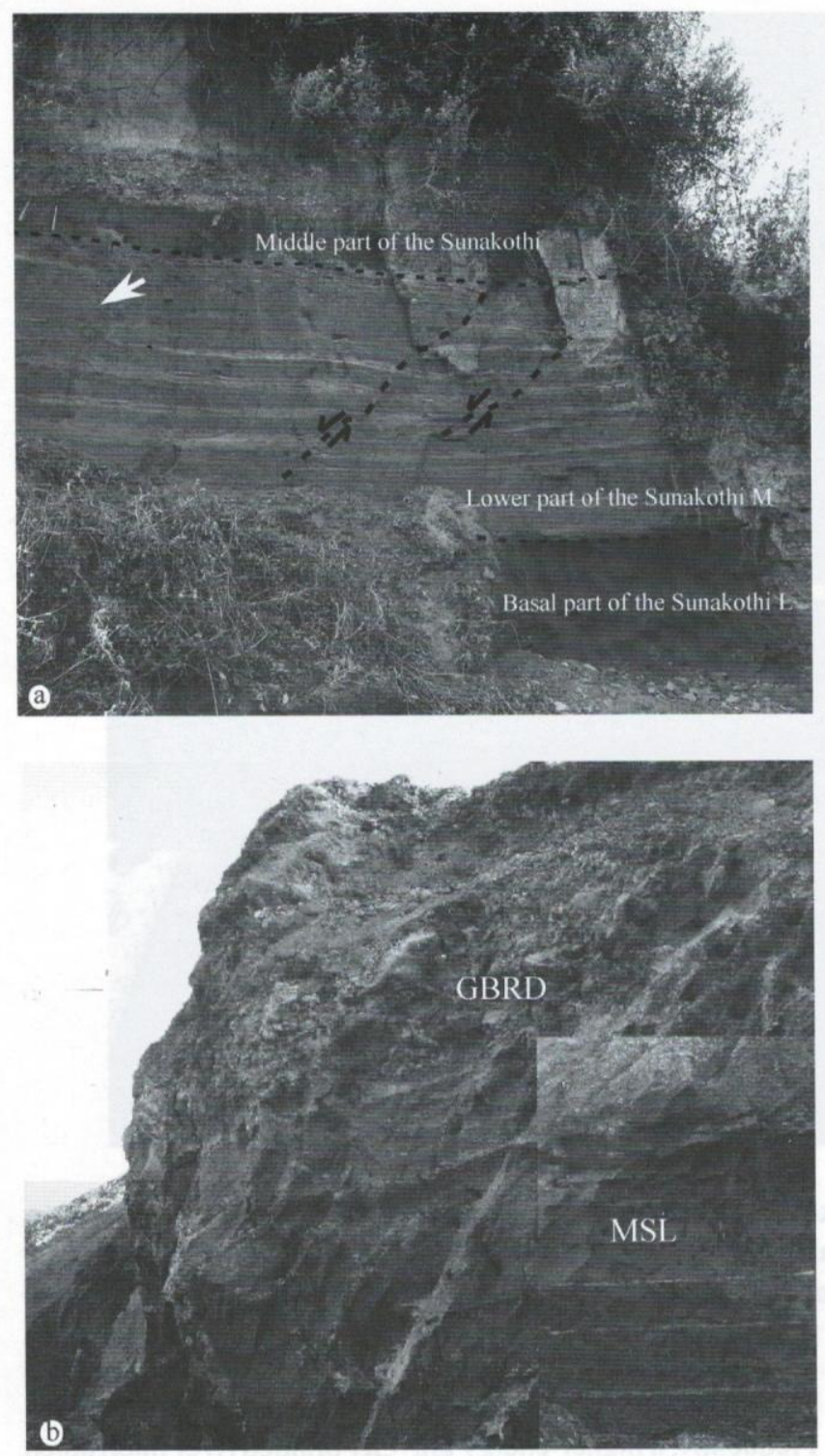

Fig. 9a: Basal, lower, and middle parts of the Sunakothi Formation; the lower part contains different synsedimentary faults and vein-filling structures; $9 \mathrm{~b}$. Upper part of the Sunakothi Formation contains marginal shallow lacustrine (MSL) sediments covered by terrace gravel deposits. Right side photograph is an enlarged view of the lacustrine muddy sequence with thin layers of cross and climbing ripple sand.

the Kalimati Formation dipping towards the centre from the southern margin and the thick fluvial gravel beds of the Sunakothi Formation showing the palaeocurrent directions from south and southeast indicate that the ruplift rate of the Mahabharat range in the south was irregular but higher than that of the Sheopuri range. The fact that the gently inclined sequence of the Sunakothi Formation is overlain by the thick and monotonous gravelly sequence of the braided river deposits, indicates that the uplift of the Mahabharata range in the south continued during and after the deposition of the Sunakothi Formation. On the other hand, thick fluvial sandy and gravelly sediments within the Sunakothi Formation indicate greater runoff and a large volume of sediment yield due to greater relief and elevated precipitation at the time of deposition. Moreover, the repetition of fine and coarse sediments indicates a seasonal high and low amount of precipitation rate within the paleo-Kathmandu Basin.

In the south, minor fluctuation in the lake level produced a progradational sequence involving muddy rhythmite at the base, and is followed by sandy and gravelly sequence of the lower and middle part of this formation. The sedimentary sequence shows a vertical and lateral increase in lenticular sand and gravel bodies (Fig.10) denoting an increase in sand supply by the river to the lake basin. The sequence also entails that the ancient lake gradually reduced when sandy and gravelly braided river extended further towards the centre of the Palaeo-Kathmandu lake. Hence, a thick fluvial clastic sequence with basin-ward coarsening gravel and sand beds of this formation indicates that both climatic and tectonic condition have played a major role for the deposition of the sediments and initiation of the regression phase of the Palaeo-Kathmandu Lake from the south.

Lake level fluctuation played a key role during the deposition of these sediments. It is also possible that tectonic activities at the basin margin could have played an additional role. Furthermore, interbedding of deformed structures (microfolds, faults, slump, sand pipe etc) and undeformed sequences indicates catastrophic events followed by periods of relative stability.

\section{CONCLUSIONS}

The newly defined Sunakothi Formation is underlain by muddy lacustrine facies of the Kalimati Formation and its top surface is covered by the terrace gravel deposits from south to central part of the Kathmandu Basin. Its middle and basal parts are thick and increase in thickness toward the basin centre. The upper part of this formation is restricted only to the southern portion, whereas the lower part gradually thins out towards the centre.

The sediments were deposited during the time of draining out of the lake. Fluvial to lacustrine deltaic process was operating during the depositional period of these sediments. Very thick lenticular gravel beds and sand beds with deep erosion surfaces indicate that the lake was rapidly lowering its water level during the deposition of these sediments. The lacustrine sequence in between the sandy and gravelly strata indicates stable or lake-level rising conditions.

The open lacustrine deposits of the Kalimati Formation are covered by the Sunakohti Formation from the south and the Gokarna or Thimi formations from the north. It indicates that the fluvio-lacustrine sediments of the Sunakothi 


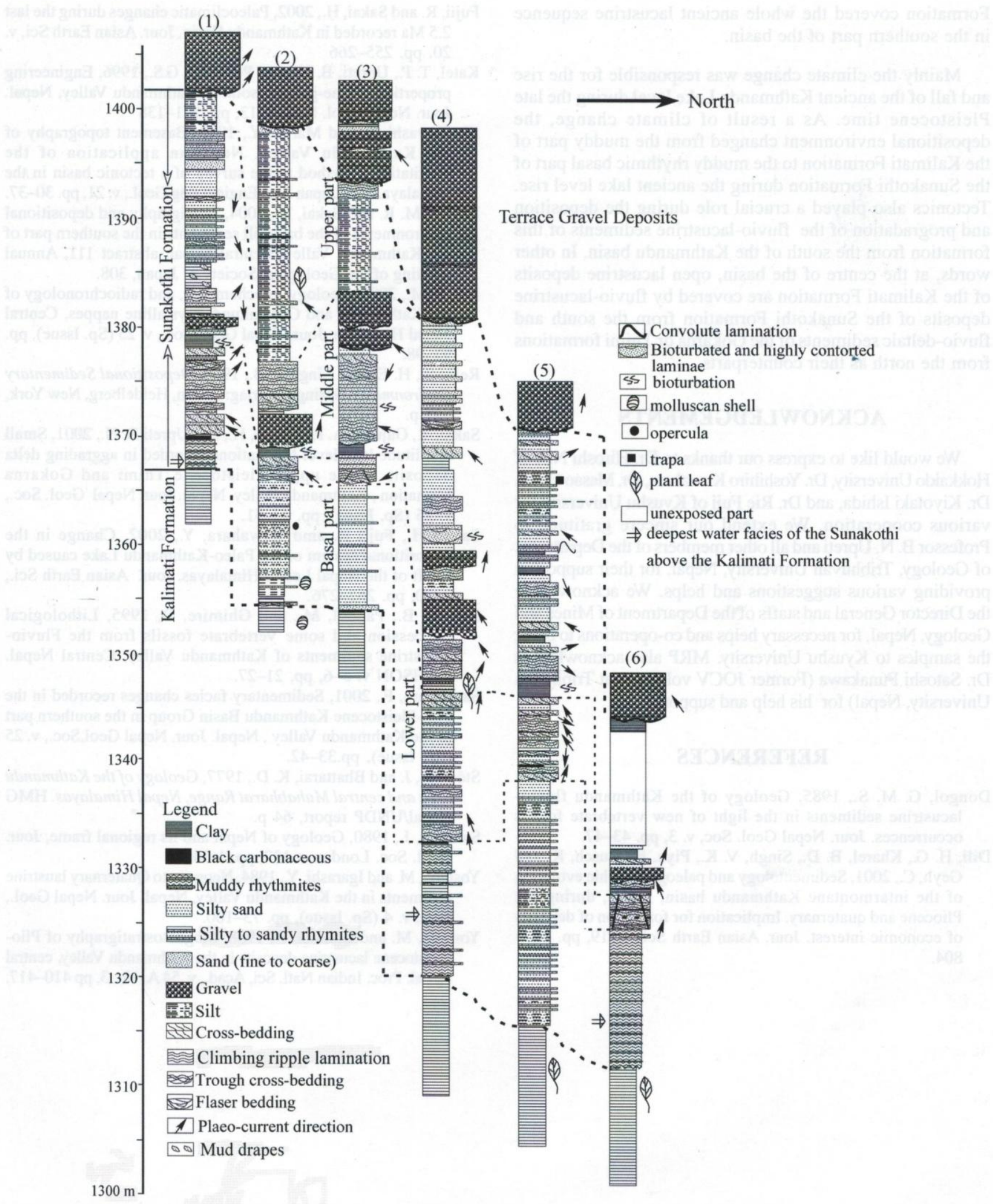

Fig. 10: Representative six measured sections showing facies changes (from south to north) in the Sunakothi Formation deposited on the open lacustrine facies of the Kalimati Formation and covered by terrace gravel deposits. 
Formation covered the whole ancient lacustrine sequence in the southern part of the basin.

Mainly the climate change was responsible for the rise and fall of the ancient Kathmandu Lake level during the late Pleistocene time. As a result of climate change, the depositional environment changed from the muddy part of the Kalimati Formation to the muddy rhythmic basal part of the Sunakothi Formation during the ancient lake level rise. Tectonics also played a crucial role during the deposition and progradation of the fluvio-lacustrine sediments of this formation from the south of the Kathmandu basin. In other words, at the centre of the basin, open lacustrine deposits of the Kalimati Formation are covered by fluvio-lacustrine deposits of the Sunakothi Formation from the south and fluvio-deltaic sediments of the Gokarna or Thimi formations from the north as their counterparts.

\section{ACKNOWLEDGEMENTS}

We would like to express our thanks to Dr. Hiroshi Nisi of Hokkaido University, Dr. Yoshihiro Kuwahara, Dr. Masao Ohno, Dr. Kiyotaki Ishida, and Dr. Rie Fuji of Kyushu University for various cooperation. We extend our sincere gratitude to Professor B. N. Upreti and all other members of the Department of Geology, Tribhuvan University, Nepal, for their support in providing various suggestions and helps. We acknowledge the Director General and staffs of the Department of Mines and Geology, Nepal, for necessary helps and co-operations to bring the samples to Kyushu University. MRP also acknowledges Dr. Satoshi Funakawa (Former JOCV volunteer at Tribhuvan University, Nepal) for his help and support.

\section{REFERENCES}

Dongol, G. M. S., 1985, Geology of the Kathmandu fluviolacustrine sediments in the light of new vertebrate fossils occurrences. Jour. Nepal Geol. Soc, v. 3, pp. 43-47.

Dill, H. G., Kharel, B. D., Singh, V. K., Piya. B., Busch, K. and Geyh, C., 2001, Sedimentology and paleogeographic evolution of the intermontane Kathmandu basin, Nepal, during the Pliocene and quaternary. Implication for formation of deposits of economic interest. Jour. Asian Earth Sci., v. 19, pp. 777804.
Fujii, R. and Sakai, H., 2002, Paleoclimatic changes during the last 2.5 Ma recorded in Kathmandu Basin, Jour. Asian Earth Sci, v. 20, pp. $255-266$

Katel, T. P., Upreti, B. N., and Pokheral, G.S., 1996, Engineering properties of fine-grained soils of Kathmandu Valley, Nepal. Jour. Nepal Geol. Soc., v. 13, pp. 121-138

Moribayashi, S. and Maruo, Y., 1980, Basement topography of the Kathmandu Valley, Nepal-an application of the gravitational method to the survey of a tectonic basin in the Himalaya. Jour. Japan Soc. Engineering Geol., v. 21, pp. 30-37.

Paudel, M. R. and Sakai, H., 2004, Stratigraphy and depositional environments of the basinfill sediments in the southern part of the Kathmandu Valley, Central Nepal, abstract 111, Annual meeting of the Geological Society of Japan, 308.

Rai, S. M., 2001. Geology, geochemistry, and radiochronology of the Kathmandu and Gosainkund crystalline nappes, Central Nepal Himalaya. Jour. Nepal Geol. Soc., v. 25 (Sp. Issue), pp. 93-98.

Reineck, H. E. and Singh, I. B., 1980, Depositional Sedimentary Environments, Springer-Verlag: Berlin, Heidelberg, New York, $551 \mathrm{p}$.

Sakai, T., Gajurel, A. P., Tabata, H., and Upreti B. N., 2001, Small amplitude lake level fluctuations recorded in aggrading delta deposits of the upper Pleistocene Thimi and Gokarna formation, Kathmandu Valley, Nepal. Jour. Nepal Geol. Soc., v. 25 (Sp. Issue), pp. 43-51.

Sakai, H., Fujii R. amd Kuwahara, Y., 2002, Change in the depositional system of the Paleo-Kathmandu Lake caused by uplift of the Nepal Lesser Himalayas. Jour. Asian Earth Sci., v. 20 , pp. 267-276.

Sah, R. B., Paudel, M., and Ghimire, D, 1995, Lithological Succession and some Vertebrate fossils from the Fluviolacustrine sediments of Kathmandu Valley, Central Nepal. NAHSON v. 5-6, pp. 21-27.

Sawamura, F., 2001, Sedimentary facies changes recorded in the Plio-Pleistocene Kathmandu Basin Group in the southern part of the Kathmandu Valley, Nepal. Jour. Nepal Geol.Soc., v. 25 (Sp. Issue), pp.33-42.

Stöcklin, J. and Bhattarai, K. D., 1977, Geology of the Kathmandu area and central Mahabharat Range, Nepal Himalayas. HMG Nepal/UNDP report, 64 p.

Stöcklin, J., 1980, Geology of Nepal and its regional frame, Jour. Geol. Soc. London, v.137, pp. 1-34.

Yoshida, M and Igarashi, Y., 1984, Neogene to Quaternary laustrine sediments in the Kathmandu Valley, Nepal. Jour. Nepal Geol., Soc., v. 4 (Sp. Issue), pp. 73-100.

Yoshida, M. and Gautam, P., 1988, Magnetostratigraphy of PlioPleistocene lacustrine deposits in the Kathmandu Valley, central Nepal. Proc. Indian Natl. Sci, Acad., v. 54 A, No. 3, pp 410-417. 